\title{
Spray-dried porcine plasma in dog foods: implications on digestibility, palatability and haematology
}

\author{
Plasma suíno spray-dried na alimentação de cães: implicações na \\ digestibilidade, palatabilidade e hematologia
}

\author{
Talita de Andrade ${ }^{1}$; Daniele Cristina de Lima ${ }^{2 *}$; Lidiane Priscila Domingues ${ }^{3}$; \\ Ananda Portella Félix ${ }^{4}$; Simone Gisele de Oliveira ${ }^{4}$; Alex Maiorka ${ }^{4}$
}

\begin{abstract}
The objective of this study was to evaluate food palatability, digestibility and blood parameter of dogs fed diets containing increasing levels of spray-dried porcine plasma (SDP). We also aimed to evaluate the SDP digestibility for dogs. We used 36 dogs distributed in 3 experiments. In the digestibility assay (Experiment 1), eight adult Beagles were distributed according to a double Latin square design (4 $\mathrm{x} 4$ ). The following diets were evaluated: $0,4,8$, and $12 \%$ SDP of diet. In the palatability trial (Experiment 2), 20 adult dogs were used. Diets containing 0 and 4\% SDP were pair-wised compared. Blood parameters (Experiment 3 ) were evaluated in eight adult Beagles. Dogs were fed the diet with $0 \%$ for 10 days and then the diet with $12 \%$ SDP for further 10 days. Dietary SDP inclusion promoted a linear increase $(\mathrm{P}<0.05)$ in the coefficients of total tract apparent digestibility (CTTAD) of dry matter (DM) and crude protein (CP). The CTTAD of DM and CP obtained by analysis of regression of the SDP were 0.981 and 0.912 , respectively. Diet palatability was reduced when $4 \%$ SDP was included in the diet $(\mathrm{P}<0.05)$. Total circulating leukocytes, total plasma protein, and albumin levels increased when $12 \%$ SDP was included in the diet $(\mathrm{P}<0.05)$, but other blood parameters were not affected $(\mathrm{P}>0.05)$. In conclusion, SDP shows high digestibility of $\mathrm{CP}$ and $\mathrm{DM}$, being feasible its use in diets for dogs. However, it is important to study the effects of inclusion levels lower than $4 \%$, in order to do not compromise diet palatability.
\end{abstract}

Key words: Blood parameters. Digestibility. Dogs. Leukocytes. Protein sources.

\section{Resumo}

O objetivo do estudo foi avaliar a digestibilidade, palatabilidade e parâmetros sanguíneos em cães alimentados com dietas contendo crescentes níveis de plasma suíno spray-dried (PSD). Ainda, objetivou-se isolar a digestibilidade do PSD em cães. Foram utilizados 36 cães distribuídos em 3 experimentos. Para o ensaio de digestibilidade (Experimento 1) foram utilizados oito cães adultos da raça Beagle, distribuídos em quadrado latino duplo (4x4). Foram avaliadas quatro dietas: $0 \%, 4 \%, 8 \%$ e 12\% PSD. Para avaliação da palatabilidade (Experimento 2) foram utilizados 20 cães adultos. Foram comparadas duas dietas: 0\% PSD vs. 4\% PSD. Para a avaliação hematológica (Experimento 3) foram utilizados oito cães adultos Beagles. Todos os cães foram alimentados com a dieta $0 \%$ PSD por 10 dias e posteriormente com a dieta contendo $12 \%$ PSD por mais 10

1 Discente, Curso de Mestrado do Programa de Pós-Graduação em Ciências Veterinárias. Universidade Federal do Paraná, UFPR, Curitiba, PR, Brasil. E-mail: talidrade@yahoo.com.br

2 Discente, Curso de Doutorado do Programa de Pós-Graduação em Zootecnia. UFPR, Curitiba, PR, Brasil. E-mail: daniele. scrobot@gmail.com

3 Discente, Curso de Mestrado do Programa de Pós-Graduação em Zootecnia, UFPR, Curitiba, PR, Brasil. E-mail: lidi_zoo@, yahoo.com.br

4 Profs., Departamento de Zootecnia, UFPR, Curitiba, PR, Brasil.E-mail: apfelix@ufpr.br; sgoliveira@ufpr.br; amaiorka@ufpr.br

* Author for correspondence 
dias. Houve aumento linear $(\mathrm{P}<0,05)$ dos coeficientes de digestibilidade aparente (CDA) da matéria seca (MS) e da proteína bruta (PB) com a inclusão de PSD na dieta. Os CDA da MS e PB do PSD, obtidos por análise de regressão foram de $98.1 \%$ e $91.2 \%$, respectivamente. O nível de 4\% PSD reduziu a palatabilidade da dieta $(\mathrm{P}<0,05)$. Houve aumento dos leucócitos totais circulantes, proteínas totais e albumina $(\mathrm{P}<0,05)$, não havendo alterações nas demais variáveis hematológicas $(\mathrm{P}>0,05)$, nos cães alimentados com $12 \%$ PSD. Conclui-se que o PSD apresenta elevada digestibilidade da PB e MS, sendo viável o seu uso em dietas para cães. Entretanto, é importante estudar os efeitos de níveis de inclusão menores que $4 \%$, a fim de não comprometer a palatabilidade da dieta.

Palavras-chave: Parâmetros sanguíneos. Digestibilidade. Cães. Leucócitos. Fontes proteicas.

\section{Introduction}

Dogs are carnivorous animals, and therefore it is essential to determine the nutritional value of protein dietary sources. Among protein sources, spray-dried porcine plasma (SDP) has high protein content (approximately $85 \%$ protein, for this study), in addition of biologically active peptides, such as albumin, transferrin, and immunoglobulin G (DIJK et al., 2001). Due to its special drying processing (spray-dried), its protein quality is preserved.

Studies showed that partially hydrolysed immunoglobulins were able to pass the gastrointestinal tract of adult dogs and cats, strengthening local immune barrier function (RODRIGUEZ et al., 2007). It was also demonstrated that the dietary SDP inclusion enhanced pig growth and immunity (BOSI et al., 2004) and improved the utilization of blood proteins (KATS et al., 1994) and diet palatability (ERMER et al., 1994).

However, there is little information available on the nutritional value of SDP for dogs (QUIGLEY et al., 2004), particularly on the digestibility of its protein. Therefore, this study aimed at evaluating the possible changes promoted by the inclusion of SDP on the digestibility and palatability of dog foods, and on dog blood parameters and faecal characteristics. The digestibility of SDP protein and DM was also evaluated.

\section{Material and Methods}

The nutritional study of SDP involved three experiments designed to evaluate the digestibility, palatability, and haematological parameters of dogs. The experiments were approved by the Ethics Committee on the use of Animals of the Agricultural Sciences Sector, Federal University of Paraná, Curitiba, PR, Brazil (046/2011).

\section{Experiment 1: Digestibility and faecal characteristics}

Diets

Four diets with increasing SDP inclusion levels $(0,4,8$, and $12 \%$ SDP of diet) were formulated. Ingredients were ground in a hammer mill to 0.8 $\mathrm{mm}$ particle size, mixed, and extruded in a singlescrew extruder (Ferraz, E-130, Ribeirão Preto, SP, Brazil). Diets were then dried in a triple-belt drier $\left(100-110^{\circ} \mathrm{C}\right)$ and sprayed with poultry fat. Spraydried porcine plasma was added on top, after the addition of liquid and powdered flavours. Diets were stored for 15 days in sealed bags on pallets in an area protected from direct sunlight at $20.5 \pm 1.2^{\circ} \mathrm{C}$ environmental temperature and $68.5 \pm 2.3 \%$ relative humidity before fed to the dogs. Food ingredients and the analysed chemical composition of diets are presented in Table 1. The analysed chemical composition (as fed) of the SDP was: $85.8 \% \mathrm{DM}$, $84.9 \%$ CP, $5.9 \%$ ether extract after acid hydrolysis (EEA), $9.2 \%$ ash, and $4532.0 \mathrm{kcal} \mathrm{kg}^{-1}$ gross energy (GE). The diets do not have equal levels of energy, $\mathrm{CP}$ and amino acids.

\section{Dogs, facilities, and digestibility assay}

Eight adult Beagle dogs ( $3 \pm 0.2$ years old) were used in this study: four males with an average 
weight of $12 \mathrm{~kg}( \pm 1.2 \mathrm{~kg})$ and four females with an average weight of $10 \mathrm{~kg}( \pm 1.1 \mathrm{~kg})$. The dogs were healthy, vaccinated, dewormed, housed individually in brick stalls with a rough concrete floor measuring $5 \times 2 \mathrm{~m}$, and provided with shelter and a solarium.

Table 1. Ingredients and analysed chemical composition of diets containing increasing levels of spray-dried porcine plasma (SDP).

\begin{tabular}{lcccc}
\hline \multirow{2}{*}{\multicolumn{1}{c}{ Item }} & \multicolumn{3}{c}{ SDP (\%) } \\
\cline { 2 - 4 } & 0 & 4 & 8 & 12 \\
\hline Ingredients (\% as fed) & 47.21 & 45.32 & 43.43 & 41.55 \\
Corn & 37.50 & 36.00 & 34.50 & 33.00 \\
Poultry offal meal & - & 4.00 & 8.00 & 12.00 \\
SDP & 10.00 & 9.60 & 9.20 & 8.80 \\
Poultry fat & 3.00 & 2.88 & 2.76 & 2.64 \\
Liquid poultry liver hydrolysate & 1.00 & 0.96 & 0.92 & 0.88 \\
Powdered poultry liver hydrolysate & 0.50 & 0.48 & 0.46 & 0.44 \\
Mineral and vitamin supplement ${ }^{1}$ & 0.50 & 0.48 & 0.46 & 0.44 \\
Sodium chloride & 0.05 & 0.05 & 0.05 & 0.05 \\
Butyl-hydroxy-toluene & 0.24 & 0.23 & 0.22 & 0.21 \\
Ammonium propionate & & & \\
Analysed chemical composition (\% dry matter) & 93.00 & 92.90 & 92.50 & 92.50 \\
Dry matter & 28.82 & 30.79 & 31.89 & 34.49 \\
Crude protein & 26.70 & 22.42 & 20.59 & 18.35 \\
Ether extract after acid hydrolysis & 8.06 & 8.29 & 8.11 & 8.00 \\
Ash & 1.90 & 1.97 & 1.80 & 1.81 \\
Crude fibre & 4532 & 5050 & 5026 & 5029 \\
Gross energy (kcal kg ${ }^{-1}$ ) & & & \\
\hline
\end{tabular}

${ }^{1}$ Vitamin and mineral supplement (content/kg): Vit. A - 16,900 IU, Vit. D3 - 2,340 IU, Vit. E - 104 ppm, Vit. K - 1.3 ppm, Vit. B1 - 3.9 ppm, Vit. B2 - 6.5 ppm, pantothenic acid - 19.5 ppm, niacin - 32.5 ppm, choline - 1150.75 ppm, iron - 104 ppm, copper - 13 ppm, iodine - $2.6 \mathrm{ppm}$, manganese $-45.5 \mathrm{ppm}$, selenium - $0.26 \mathrm{ppm}$.

The trial was performed using the method of total faeces collection, according to the Association of American Feed Control Officials (2004) guidelines. The experimental period included 5 days of adaptation to the diets and to the facilities and 5 days of total faeces collection. Dogs were fed twice daily (07:30 and 16:00) in amounts sufficient to supply their metabolisable energy (ME) requirements (kcal day ${ }^{-1}$ ): $130 \mathrm{x}$ body weight ${ }^{0.75}$, according to the recommendations of the National Research Council (2006). Water was offered ad libitum.
Faeces were collected and weighed at least twice daily, pooled bind to the treatment per dog, and frozen $\left(-14^{\circ} \mathrm{C}\right)$. At the time of faecal collection, faecal score and output were evaluated. Faecal texture was scored according to 1 to 5 scale, where 1 indicates watery faeces and 5, well-shaped, hard, and dry stools (CARCIOFI et al., 2009).

At the end of the collection period, faeces were thawed and dried in a forced-ventilation oven at $55^{\circ} \mathrm{C}$ (320-SE, Fanem, São Paulo, Brazil) until a constant weight was obtained. After drying, faeces 
and diets were ground to $1 \mathrm{~mm}$ particle size and analysed for DM, by drying the samples in a forcedventilation oven at a temperature of $105^{\circ} \mathrm{C}$ for 12 hours, CP (method 954.01), ash (method 942.05), crude fibre (CF, method 962.10), and EEA (method 954.02) contents according to the Association of the Official Analytical Chemists (1995). The GE was determined using an isoperibol bomb calorimeter (Parr Instrument Co., model 1261, Moline, IL, USA). The coefficients of total tract apparent digestibility (CTTAD) and the ME, without urine collection, were estimated according to guidelines from the Association of American Feed Control Officials (2004) using the following equations:

CTTAD $=(\mathrm{g}$ ingested nutrient $-\mathrm{g}$ excreted nutrient)/g ingested nutrient

$\operatorname{ME}\left(\mathrm{kcal} \mathrm{g}^{-1}\right)=\left\{\mathrm{kcal} \mathrm{g}^{-1}\right.$ GE intake - $\mathrm{kcal} \mathrm{g}^{-1}$ faecal GE - [(g CP intake - g faecal CP ) x $1.25 \mathrm{kcal}$ $\left.\left.\mathrm{g}^{-1}\right]\right\} / \mathrm{g}$ intake

\section{Statistical analysis}

The data were analysed according to double Latin square design $(4 \mathrm{x} 4)$, with four periods, four diets, and eight dogs, totalling eight replicates per treatment. The results were tested for normality (Shapiro-Wilk) and homogeneity of variance (Bartlett) and when this assumption was accepted, data were submitted to analysis of variance using the GLM procedures of SAS statistical package (version 8, SAS Institute Inc., Cary, NC, USA). Regression analysis at a 5\% probability concentration using PROC REG was performed based on the percentage of SDP included and the CTTAD. The spray-dried egg levels were added in substitution of the same amount of the control diet $(\mathrm{Cd})$. The diets containing SDE are referred as test diets (Td). The following equation was used to determine the individual digestibility of nutrients in: $\mathrm{CTTAD}_{\mathrm{Td}}=\mathrm{CTTAD}_{\mathrm{SDE}}+\left(\mathrm{CTTAD}_{\mathrm{Cd}}\right.$ - $\left.\mathrm{CTTAD}_{\mathrm{Td}}\right) \times \%$ contribution of the nutrient of the $\mathrm{Cd}$ in the $\mathrm{Td}$. The faecal score was analysed using the Kruskal-Wallis test at a probability of $5 \%$.

\section{Experiment 2: Palatability study}

\section{Animals and facilities}

In this test, 20 adult dogs (10 males and 10 females) were individually housed in concrete kennels with solarium ( $5 \mathrm{~m} \times 2 \mathrm{~m})$. The following breeds, number of dogs per breed, and average ( \pm standard deviation) body weight were tested: Beagle $(8 ; 12.1 \pm 1.3 \mathrm{~kg})$, Labrador $(4 ; 28.2 \pm 2.7$ $\mathrm{kg})$, Basset Hound $(4 ; 21.9 \pm 2.2 \mathrm{~kg})$, and Siberian husky $(4 ; 20.8 \pm 1.9 \mathrm{~kg})$. Dogs were previously examined, vaccinated, and drenched (Drontal plus, Bayer, Belford Roxo, RJ, Brazil).

\section{Experimental protocol}

Palatability was measured using a pair-wise diet comparison (GRIFFIN, 2003) of diets 0 vs. $4 \%$ SDP. The objective was to evaluate the effect of minimum SDP dietary level on food palatability and intake.

The dogs were offered food at 1.3 times their daily energy maintenance requirements as recommended by the National Research Council (2006): (kcal day $\left.{ }^{1}\right)=169 \mathrm{x}$ body weight ${ }^{0.75}$. The two tested diets were simultaneously offered in two identical bowls once daily (17:00) to the dogs for a period of 30 minutes for two consecutive days. The position of the bowls was changed daily in order to prevent the bias of feeding always at the same location. The intake of each diet was calculated as the total amount of diet offered minus the amount of diet remaining in the bowl at the end of the 30 min period during the two days. The food the dog chose first (first food visited) was recorded. Water was supplied ad libitum.

Food preference was calculated based on the intake ratio of the basal diet ( $0 \% \mathrm{SDP})$ as follows: intake ratio of basal diet $=$ intake $(\mathrm{g})$ of basal diet/ total intake $(\mathrm{g})$ of basal $+4 \%$ SDP diets. 


\section{Statistical analysis}

Palatability was analysed using 40 observations (20 dogs $\times$ two test days). Data were first submitted to the Kruskal-Wallis test, which did not detect any influence $(\mathrm{P}>0.05)$ of the breed (Beagle, Labrador, Basset Hound, and Siberian husky), sex (male and female), or test day (day one and day two) on the number of visits to the food bowl with the basal diet or on the intake ratio of basal diet. Therefore, the intake ratio data were analysed by the paired t-test of SAS statistical package (version 8, SAS Institute Inc., Cary, NC, USA) to determine if the intake ratio of the basal diet was different from 0.50, at $\mathrm{P}<0.05$. A food intake ratio greater than 0.50 , according to the t-test, indicates preference for basal diet, whereas an intake ratio of less than 0.50 indicates preference for $4 \%$ SDP.

The number of first visits to the food bowls with diets basal and 4\% SDP was analysed using the Chi-squared test at a $5 \%$ probability level. The expected frequency was equal to 20 , as there were 40 observations.

\section{Experiment 3: Blood evaluation}

\section{Animals and facilities}

Eight adult Beagles were used (four males and four females) for the haematological evaluation. The animals were housed individually in brick stalls with concrete floors, measuring $5 \times 2 \mathrm{~m}$, and shelter and a solarium.

\section{Experimental protocol}

Blood evaluation was conducted for 20 days divided in two periods of 10 days each. The basal diet ( $0 \%$ SDP) was fed to all dogs during the first 10 -day period, and the $12 \%$ SDP diet was fed to all dogs during the second 10 day period.

During the experiment, dogs were fed once daily in sufficient amount to supply their ME requirements
( $\mathrm{kcal}$ day $^{-1} ; 130 \mathrm{x}$ body weight ${ }^{0.75}$ ), according to the National Research Council (2006). At the end of both periods, blood samples were collected after 23 hours of feed fasting and 12 hours of water fasting by jugular vein puncture. Three $\mathrm{ml}$ was collected with EDTA as anti-clotting agent for blood count and 3 $\mathrm{ml}$ with no anti-clotting agent for serum analyses. The following parameters were evaluated: Number and concentration of erythrocytes and haemoglobin, total leukocytes, albumin, globulin, blood proteins, and total protein.

Total protein and albumin were measured using a commercial chemical kit (Dialab®) and a chemical analysis equipment (BS-200, Mindray Chemistry Analyser $\left.{ }^{\circledR}\right)$. Blood analyses were performed using the equipment BC 2800 vet (Mindray AutoHematologic Analyzer $($ ).

Cell-count slides were stained using the diff-quick method. Globulin concentration was determined as the differences between total protein and albumin concentrations.

\section{Statistical analysis}

Data were analysed according to a completely randomized experimental design, with eight replicates per treatment, by the Student's t-test at $5 \%$ probability level.

\section{Results and Discussion}

\section{Experiment 1: Digestibility and faecal characteristics}

There was no effect $(\mathrm{P}>0.05)$ of SDP on food intake (average of $231 \pm 2.3 \mathrm{~g} / \mathrm{dog} /$ day). The dietary inclusion of SDP linearly increased the CTTAD of DM and CP $(\mathrm{P}<0.05)$. When SDP digestibility was isolated by regression analysis, this ingredient presented high DM and CP digestibility (Table 2). No differences in faecal output, score, $\mathrm{pH}$ or $\mathrm{DM}$ content were detected $(\mathrm{P}>0.05$, Table 2$)$. 
Table 2. Coefficients of total tract apparent digestibility (CTTAD, \%) and metabolisable energy content $\left(\mathrm{kcal} \mathrm{kg}^{-1}\right)$ of the diets containing spray-dried porcine plasma (SDP), CTTAD of dry matter and crude protein of SDP, and faecal characteristics of dogs.

\begin{tabular}{|c|c|c|c|c|c|c|c|c|}
\hline \multirow{2}{*}{ Item } & \multirow{2}{*}{ SDP } & \multicolumn{4}{|c|}{ Dietary SDP (\%) } & \multirow{2}{*}{ SEM } & \multicolumn{2}{|c|}{$P$} \\
\hline & & 0 & 4 & 8 & 12 & & $\mathrm{~L}$ & Q \\
\hline \multicolumn{9}{|c|}{ CTTAD } \\
\hline Dry matter & 98.1 & 82.5 & 82.8 & 83.4 & 84.0 & 0.02 & 0.021 & 0.725 \\
\hline Crude protein & 91.2 & 85.2 & 85.4 & 85.7 & 87.4 & 0.03 & 0.009 & 0.181 \\
\hline Ether extract & - & 95.6 & 95.6 & 95.3 & 95.2 & 0.01 & 0.139 & 0.816 \\
\hline Gross energy & - & 88.8 & 88.8 & 88.9 & 89.1 & 0.02 & 0.506 & 0.845 \\
\hline ME & - & 4035 & 4047 & 4056 & 4056 & 7.54 & 0.221 & 0.833 \\
\hline \multicolumn{9}{|c|}{ Faecal characteristics } \\
\hline Dry matter (\%) & - & 35.8 & 36.2 & 34.9 & 36.3 & 2.64 & 0.381 & 0.052 \\
\hline Score $^{\mathrm{a}}$ & - & 3.7 & 3.5 & 3.7 & 3.6 & 0.21 & - & - \\
\hline $\mathrm{pH}$ & - & 6.73 & 6.57 & 6.68 & 6.76 & 0.23 & 0.286 & 0.23 \\
\hline Faecal output ${ }^{\mathrm{b}}$ & - & 0.25 & 0.27 & 0.30 & 0.28 & 0.03 & 0.331 & 0.920 \\
\hline
\end{tabular}

SEM, standard error of the mean; P, Probability of linear (L) and quadratic (Q) effects.

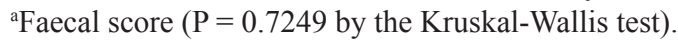

${ }^{b}$ Faecal production on fresh matter basis $(\mathrm{g}) /$ dry matter intake $(\mathrm{g}) /$ day.

Spray-dried plasma is widely used in animal feeds to improve feed intake, growth rate, feed efficiency, and intestinal health (KATS et al., 1994), but there is no information on the digestibility of individual SDP nutrients in dogs. The results obtained in the present study indicate that in addition of being rich in protein, SDP protein is highly digestible. The increase in dietary CP and DM digestibility was also observed by Quigley et al. (2004) when evaluating the effect of the addition of $0-3 \%$ SDP in dog foods.

In this study, the inclusion of SDP in the diet did not change ME levels or the CTTAD of EEA, probably because of the low level of EEA (5.9\%) and high ash content (9.2\%) of SDP. In addition, SDP did not change faecal output. Differently from Quigley et al. (2004), who observed lower faecal output and higher fat digestibility in dogs fed diets containing SDP.

Several studies with piglets showed greater dietary nutrient digestibility and weight gain when SDP was added to the post-weaning diet. Those studies attribute these improvements to the immune- protective effect of SDP on intestinal health rather than to its nutritional effects (KATS et al., 1994; DIJK et al., 2001; POLO et al., 2005). However, we did not evaluate intestinal health parameters to affirm these hypotheses in dogs.

\section{Experiment 2: Palatability}

The dog's first visit was for the 0\% SDP diet rather than the $4 \%$ SDP diet $(\mathrm{P}<0.05)$. The $0 \%$ SDP diet also presented greater intake ratio when compared with the diet containing 4\% SDP $(\mathrm{P}<0.05$, Table 3).

In the present study, the inclusion of 4\% SDP in the food reduced diet palatability. These results are opposite to the findings of Quigley et al. (2004) and Dijk et al. (2001) in piglets, who reported that up to $6 \%$ SDP in the diets increased feed intake after weaning. However, Henn et al. (2013) observed lower fed intake for broilers fed with SDP between 1 and 21 days. 
Table 3. First choice and intake ratio of dogs fed the basal diet and the diet with $4 \%$ inclusion of spray-dried porcine plasma (SDP).

\begin{tabular}{lccc}
\hline Item & $0 \%$ & $4 \%$ & $\mathrm{P}$ \\
\hline First choice $^{\mathrm{a}}$ & 0.65 & 0.35 & 0.010 \\
Intake ratio $^{\mathrm{b}}$ & 0.57 & 0.43 & $<0.001$ \\
\hline
\end{tabular}

${ }^{a}$ First choice analysed by the Chi-square test $(\mathrm{P}<0.05)$.

${ }^{\mathrm{b}}$ Intake ratio analysed by the Student's t-test $(\mathrm{P}<0,05)$.

Although most dogs preferred the basal diet ( $0 \%$ SDP) when it was simultaneously offered with the diet containing 4\% SDP, food intake was not different when the diets were individually offered in the digestibility trial. This shows that dogs do not refuse foods containing up to $12 \%$ SDP, although when given the choice, they may prefer eating diets with no SDP. Quigley et al. (2004) also did not find any differences in food intake when dogs were fed diets containing up to $3 \%$ SDP. Considering that $4 \%$ SDP of diet is above the commercial inclusion level of this ingredient ( 1 to $3 \%$ ), is important to evaluate the impact of lower SDP inclusions on diet palatability in dogs.

Several factors may affect food palatability, particularly aroma, texture, and kibble shape and size (ARAUJO; MILGRAM, 2004). In addition, species peculiarities, animal age, and the interaction of SDP with other dietary ingredients may influence diet intake. Besides, differences on nutritional composition between control and 4\% SDP diets may also have contributed to the palatability results found.

\section{Experiment 3: Blood evaluation}

The diet containing 12\% SDP increased the number of total leukocytes and the concentrations of total blood proteins and albumin $(\mathrm{P}>0.05)$, which, however, were within the normal range. The dietary inclusion of $12 \%$ SDP did not affect the other evaluated blood parameters $(\mathrm{P}>0.05)$, as shown in Table 4.

Table 4. Blood parameters of dogs fed first the basal diet and then a diet containing $12 \%$ spray-dried porcine plasma (SDP).

\begin{tabular}{lcccc}
\hline Item & $0 \%$ & $12 \%$ & SEM & P \\
\hline Erythrocytes $\left(\mathrm{mm}^{3}\right)$ & 6.4 & 6.5 & 0.13 & 0.972 \\
Haematocrit $(\%)$ & 45.1 & 44.3 & 0.71 & 0.533 \\
Haemoglobin $\left(\mathrm{g} \mathrm{dL}^{-1}\right)$ & 15.6 & 15.5 & 0.33 & 0.891 \\
Total leukocytes $\left(\mathrm{n} \mu \mathrm{L}^{-1}\right)$ & 9414.3 & 11514.0 & 675.68 & 0.037 \\
Blood proteins $\left(\mathrm{g} \mathrm{dL}^{-1}\right)$ & 6.7 & 6.7 & 0.10 & 0.779 \\
Total proteins $\left(\mathrm{g} \mathrm{dL}^{-1}\right)$ & 6.1 & 6.4 & 0.18 & 0.022 \\
Albumin $\left(\mathrm{g} \mathrm{dL}^{-1}\right)$ & 3.2 & 3.5 & 0.05 & 0.019 \\
Globulins $\left(\mathrm{g} \mathrm{dL}^{-1}\right)$ & 2.6 & 2.8 & 0.08 & 0.373 \\
\hline
\end{tabular}

SEM: standard error of the mean; P: probability considered significant when $\mathrm{P}<0.05$ by the Student's t-test $(\mathrm{n}=8)$. 
Blood responses to a specific food are extremely important to evaluate its quality and purpose. In the present study, dogs fed SDP presented an increased number of circulating leukocytes and total protein and albumin concentration, although these were within the normal ranges. Blood defence cells are responsible for fighting external invaders (COLVILLE; BASSERT, 2010), and SDP is widely used as an intestinal health promoter in piglets because it contains active immunoglobulins.

Coffey and Cromwell (2001) reported that SDP enhances immunocompetence in pigs. According to those authors, the immune components present in that ingredient contribute to improve intestinal health by increasing intestinal villi surface and enzyme activity. Thereby improving digestion and allowing better absorption of the dietary nutrients.

Still, according to Boyer et al. (2015), the inclusion of 5\% SDP increased immunological responses in early-life pigs. The same was observed by $\mathrm{Hu}$ et al. (2016), which related benefits for growth performance of piglets with inclusion of $2 \%$ SDP combined with $2 \%$ of yeast-deprived protein. According to Kats et al. (1994), the increase in serum albumin levels in piglets fed SDP improves blood protein quality and utilization. Moreover, higher albumin circulating levels allow better control of the oncotic pressure, aiding cell metabolism. The obtained increase in total protein level was mainly due to the higher albumin level, as that increase mathematically corresponded to the increase in serum albumin.

It is important to highlight that the haematological results found in the present study may be also due to the higher CP level in the diet containing 12\% SDP, compared with the control diet (34.4 vs. $28.8 \% \mathrm{CP}$, respectively). The nutritional differences among diets are a limitation of the regression method used in this study to isolate SDP digestibility. In this method, we used high SDP inclusion levels, in substitution of control diet formula, to reduce prediction errors of ingredient digestibility. But, in commercial dog food formulations, practical inclusion levels of SDP are up to $3 \%$. Unfortunately, it was not possible to evaluate the blood parameters of dogs fed the other SDP levels (4 and 8\%). Therefore, it is important that more studies be conducted to analyse the biological effects of lower SDP inclusion in dog diets.

\section{Conclusions}

Spray-dried porcine plasma, despite not being very palatable to adult dogs, when used $4 \%$ inclusion, is an alternative protein source with high digestibility, and does not affect dog's faecal characteristics. Under the conditions of this study, $12 \%$ SDP inclusion also increases the circulating levels of leukocytes, as well as blood total protein and albumin concentrations.

\section{Acknowledgements}

We acknowledge VBalimentos for manufacturing the diets.

\section{References}

ARAUJO, J. A.; MILGRAM, N. W. A novel cognitive palatability assesssment protocol for dogs. Journal of Animal Science, Oxford, v. 82, n. 7, p. 2200-2206, 2004. DOI: $10.2527 / 2004.8272200 x$

ASSOCIATION OF AMERICAN FEED CONTROL OFFICIALS - AAFCO. Dog and cat nutrient profiles. Official Publications of the Association of American Feed Control Officials Incorporated. Oxford: AAFCO, 2004.

ASSOCIATION OF THE OFFICIAL ANALYTICAL CHEMISTS - AOAC. Official methods of analysis. $16^{\text {th }} \mathrm{ed}$. Washington: AOAC, 1995.

BOSI,P.; CASINI, L.; FINAMORE,A.; CREMOKOLINI, C.; MERIALDI, G.; TREVISI, P.; NOBILI, F.; MENGHERI, E. Spray-dried plasma improves growth performance and reduces inflammatory status of weaned pigs challenged with enterotoxigenic Escherichia coli K88. Journal of Animal Science, Oxford, v. 82, n. 6, p. 1764-1772, 2004. DOI: $10.2527 / 2004.8261764 x$

BOYER, P. E.; COSTA, S. D.; EDWARDS, L. L.; MILLOWAY, M. Early-life dietary spray-dried plasma influences immunological and intestinal injury responses to 
later-life Salmonella typhimurium challenge. British Journal of Nutrition, Cambridge, v. 113, n. 5, p. 783-793, 2015. DOI: $10.1017 / \mathrm{S} 000711451400422 \mathrm{X}$

CARCIOFI, A. C.; OLIVEIRA, L. D.; VALÉRIO, A. G.; BORGES, L. L.; CARVALHO, F. C.; BRUNETTO, M. A.; VASCONSELLOS, R. S. Comparison of micronized whole soybeans to common protein sources in dry dog and cat diets. Animal Feed Science and Technology, Oxford, v. 151, n. 3, p. 251-260, 2009. DOI: 10.1016/j.anifeedsci.2009.01.002

COFFEY, R. D.; CROMWELL, G. L. Use of spray-dried animal plasma in diets for weanling pigs. Pig News and Info, Oxfordshire, v. 22, n. 2, p. 39-48, 2001.

COLVILLE, T.; BASSERT, J. M. Anatomia e fisiologia clínica para medicina veterinária. 2. ed. Rio de Janeiro: Elsevier, 2010. 543 p.

DIJK, A. J.; HEVERTS, H.; NABUURS, M. J.A.; MARGRY, R. J. C. F.; BEYNEN, A. C. Growth performance of weanling pigs fed spray-dried animal plasma: a review. Livestock Production Science, Amsterdam, v. 68, n. 2, p. 263-274, 2001. DOI: 10.1016/S0301-6226(00)00229-3

ERMER, P.; MILLER, P. S.; LEWIS, A. J. Diet preference and meal patterns of weanling pigs offered diets containing either spray-dried porcine plasma or dried skim milk. Journal of Animal Science, Oxford, v. 72, n. 6, p. 1548-1554, 1994. DOI: $10.2527 / 1994.7261548 \mathrm{x}$

GRIFFIN, R. Pet food technology. In: GRIFFIN, R. Palatability testing methods: parameters and analyses that influence test conditions, Mt. Morris: Watt Publishing Co., 2003. cap 1, p. 187-193.

HENN, J. D.; BOCKOR, L.; VIEIRA, M. S.; RIBEIRO, A. M. L.; KESSLER, A. M.; ALBINO, L.; ROSTAGNO, H.; CRENSHAW, J. D.; CAMPBELL, J. M.; RANGEL, L. F. S. Inclusion of porcine spray-dried plasma in broiler diets. Poultry Science, Oxford, v. 22, p. 229-237, 2013. DOI: 10.3382/japr.2012-00613
HU, L.; CHE, L.; LUO, G.; SU, G.; FEI, H.; XUAN, Y.; FANG, Z.; LIN, Y.; XU, S.; YANG, W.; WU, Z.; WU, D. Effects of yeast-derived protein vs spray-dried porcine plasma supplementation on growth performance, metabolism and immune response of weanling piglets. Italian Journal of Animal Science, Milan, v. 13, n. 4, p. 163-168, 2016. DOI: 10.4081/ijas.2014.3154

KATS, L. J.; NELSSEN, J. L.; TOKACH, M. D.; GOODBAND, R. D.; WEEDEN, T. L.; DRITZ, S. S.; HANSEN, J. A.; FRIESEN, K. G. Effects of spray-dried blood meal on growth performance of the early weaned pig. Journal of Animal Science, Oxford, v. 72, n. 11, p. 2860-2869, 1994. DOI: $10.2527 / 1994.72112860 x$

NATIONAL RESEARCH COUNCIL. NUTRIENT REQUIREMENTS OF DOGS AND CATS - NRC. National academy press. Washington: NRC, 2006. 424 p.

POLO, J.; RODRIGUES, C.; SABORIDO, N.; RODENAS, J. Functional properties of spray-dried animal plasma in canned petfood. Animal Feed Science and Technology, Oxford, v. 122, n. 3, p. 331-343, 2005. DOI: 10.1016/j. anifeedsci.2005.03.002

QUIGLEY, J. D.; CAMPBELL, J. M.; POLO, J.; RUSSELL, L. E. Effects of spray-dried animal plasma on intake and apparent digestibility in dogs. Journal of Animal Science, Oxford, v. 82, n. 6, p. 1685-1692, 2004. DOI: $10.2527 / 2004.8261685 \mathrm{x}$

RODRIGUEZ, C.; BLANC, F.; ROMANO, V.; SABORIDO, N.; RODENAS, J.; POLO, J. Porcine immunoglobulins survival in the intestinal tract of adult dogs and cats fed dry food kibbles containing spray-dried porcine hemacia (SDPP) or porcine immunoglobulin concentrate (PIC). Animal Feed Science and Technology, Oxford, v. 139, n. 3, p. 201-211, 2007. DOI: 10.1016/j.anifeedsci.2007.01.012 
